UDK: $355.58(4-672 E U)$

Pregledni naučni rad

Biblid: 1451-3188, 19 (2020)

God XIX, br. 73-74, str. 61-71

Primljen 31.08.2020.

DOI: https://doi.org/10.18485/iipe_ez.2020.19.73_74.5

Odobren 06.10.2020.

\title{
ODLUKA BR. 1313/2013/EU \\ EVROPSKOG PARLAMENTA I SAVETA \\ OD 17. DECEMBRA 2013. GODINE O MEHANIZMU CIVILNE ZAŠTITE UNIJE
}

\begin{abstract}
Aleksandar JAZIĆ*
Apstrakt: Prevencija različitih katastrofa jedan je od ključnih aspekata snažnijih aktivnosti Evropske unije u oblasti civilne zaštite. Cilj je bio stvaranje efikasnije civilne zaštite u skladu sa savremenim pretnjama koje donose katastrofe. Zbog toga je Evropska unija stvorila Mehanizam civilne zaštite Unije. Svrha ovog Mehanizma je da učini delovanje Evropske unije na polju sprečavanja i otklanjanja posledica katastrofa efikasnijim. Možda je najvažniji razlog mnogo puta viđena pojava da katastrofa u jednoj državi izaziva posledice u drugoj. Takođe se dogodilo da se katastrofa pojavi u nekoliko susednih država istovremeno. Za Evropsku uniju to takođe znači da katastrofa u državi koja nije članica može pogoditi neke od država članica. Svaka katastrofa, zbog posledica, izaziva preusmeravanje finansijskih i ekonomskih resursa. To uvek snažno utiče na normalno funkcionisanje svake države članice i na rad Evropske unije u celini. Te činjenice uzrokovale su stvaranje Mehanizma civilne zaštite Unije sa ciljem, pre svega, da spreči moguće katastrofe. Sa druge strane, svrha ovog Mehanizma je da omogući brzu stabilizaciju ekonomskih i političkih sistema država članica kada katastrofa bude završena.

Ključne reči: prevencija, katastrofe, vanredne situacije, civilna zaštita, Mehanizam civilne zaštite Unije, Evropska unija, Srbija.
\end{abstract}

\section{1) SVRHA}

Na teritoriji Evropske unije (EU) već dugi niz godina postoje značajne aktivnosti na jačanju kapaciteta civilne zaštite. Osnovni cilj ovih aktivnosti je sprečavanje

\footnotetext{
*Naučni saradnik, Institut za međunarodnu politiku i privredu, Beograd, e-mail: jazic@diplomacy.bg.ac.rs

Rad je nastao u okviru projekta „Srbija i izazovi u međunarodnim odnosima 2020. godine”, koji finansira Ministarstvo prosvete, nauke i tehnološkog razvoja Republike Srbije, a realizuje Institut za međunarodnu politiku i privredu tokom 2020. godine.
} 
katastrofa i umanjivanje njihovih posledica. Poznato je da katastrofe često izlaze izvan granica jedne države i pogađaju jednu ili više susednih, bez obzira koji je faktor presudno uticao na njihovu pojavu. Zato se može dogoditi da se katastrofe koje su nastale u državama koje nisu članice EU, a njen su sused, prenesu na teritoriju jedne ili više država članica. Jasno je da katastrofe imaju negativne posledice po stabilan razvoj EU. Dodatna negativna posledica je činjenica da sanacija posledica katastrofa često zahteva velika finansijska sredstva. U takvim situacijama sredstva namenjena za razvoj različitih delova EU preusmeravaju se u fondove za eliminisanje posledica katastrofa. Do ovog trenutka su sve članice EU razvile u celini, ili su podigle na visok nivo, svoje planove za reagovanje u slučaju katastrofa. Radi se o vanrednim situacijama koje katastrofe izazivaju. Da bi se postigao veći efekat u reagovanju na katastrofe neophodno je čvršće povezivanje pojedinačnih planova aktivnosti u vanrednim situacijama svih država članica u jednu celinu. Time se osigurava brži i efikasniji odgovor u vanrednim situacijama na celoj teritoriji EU, bez suvišnog trošenja resursa.

Više aktivnosti na polju utvrđivanja uzroka i karakteristika katastrofa, odnosno na polju prevencije, omogućava njihovo sprečavanje, kao i brzo eliminisanje posledica u slučaju njihovih pojava. Zato je potreba za većim razvojem prevencije katastrofa primorala EU da definiše ključne aspekte u oblasti preventivnog delovanja. Ti aspekti mogu se svesti na sledeće: formiranje baze podataka o katastrofama, veći nivo praktičnog delovanja, izrada geografskih karata baziranih na smernicama o mogućim opasnostima i rizicima, kao i veći nivo investiranja u istraživačke delatnosti u vezi katastrofa. Planovi koji treba da budu efikasan odgovor na katastrofe iziskuju da EU neguje dobru upravljačku politiku, a isti uslov važi i za njene članice. Da bi upravljačka politika u ovoj oblasti bila dobro, odnosno da bi planovi dali željen rezultat, potrebne su adekvatne mere. Pomenute mere treba u svojoj osnovi da imaju razmenu iskustava među subjektima, ali i zajedničke aktivnosti u praksi. Takođe, važno je da pripadnici civilne zaštite u svim državama EU imaju dobru obuku i da unutar država članica proširi svest o značaju prevencije katastrofa. Nadležni subjekti treba da imaju stalnu komunikaciju kako bi se saradnja držala na visokom nivou. Jedan od najvažnijih aspekata pomenutih mera je konstantan razvoj sistema ranog upozoravanja. Ovaj sistem treba da omogući dodatno dragoceno vreme neophodno za sprečavanje katastrofa, posebno što se radi o sistemu koji se aktivira odmah po pojavi katastrofe. Dosadašnji pristup EU u vidu politika i programa doprineo je jačanju svesti o značaju prevencije katastrofa. EU najviše pažnje pridaje boljem raspoređivanju sredstava, kao i boljem uređenju zakonodavstva kojim se reguliše pitanje prevencije katastrofa. ${ }^{1}$

\footnotetext{
${ }^{1}$ Videti: "A Community approach on the prevention of natural and man-made disasters", Commission of the European Communities, COM (2009) 82 final, 23.2.2009, Brussels, pp. 4-8.
} 
Prvi put je Mehanizam Zajednice oblikovan i formiran 2001. godine kada je Savet EU doneo „Odluku o osnivanju Mehanizma Zajednice da bi se olakšalo jačanje saradnje u intervencijama pomoći civilne zaštite". Ovom Odlukom istaknuta je važnost kontinuiranog razvoja zaštite u slučaju katastrofa. Obuhvaćene su vanredne situacije različitog karaktera od prirodnih do radioloških. Odluka se nije odnosila samo na države članice EU već i na njene susede, kao i na treće države. Tadašnji planovi u slučaju katastrofe i programi delovanja civilne zaštite dobili su novu snagu formiranjem Mehanizma Zajednice. To je poseban značaj imalo za vanredne situacije koje zahtevaju brzo delovanje i gde prvi odgovor na katastrofe ima najveći značaj. Temelj Mehanizma Zajednice činilo je postojeće zakonodavstvo EU.Značajan aspekt je činjenica da Odluka nije izmenila odnose država članica koji su već bili formirani putem bilateralnih i multilateralnih sporazuma u vezi sa organizacijom civilne zaštite i njenog delovanja u vanrednim situacijama. ${ }^{2}$ Konkretnije povezivanje država članica u oblasti civilne zaštite i objedinjavanje planova u jedan širi okvir u istoj oblasti dogodilo se 2007. godine osnivanjem Mehanizma civilne zaštite Zajednice. ${ }^{3}$

\section{2) MERE EU}

- "A Community approach on the prevention of natural and man-made disasters", Commission of the European Communities, COM (2009) 82 final, 23.2.2009, Brussels.

- "Decision No 1313/2013/EU of the European Parliament and of the Council of 17 December 2013 on a Union Civil Protection Mechanism", Official Journal of the European Union, L 347, 20 December 2013.

- "EU Strategy for supporting disaster risk reduction in developing countries", Commission of the European Communities, COM (2009) 84 final, Brussels, 23.2.2009.

- "Risk Assessment and Mapping Guidelines for Disaster Management", European Commission, SEC (2010) 1626 final, Brussels, 21.12.2010.

- "Towards Better Protecting Citizens against Disaster Risks: Strengthening Early Warning Systems in Europe", Commission of the European Communities, SEC (2007) 1721, Brussels, 14.12.2007.

\footnotetext{
${ }^{2}$ Videti: "Council decision of 23 October 2001 establishing a Community mechanism to facilitate reinforced cooperation in civil protection assistance intervention", Official Journal of the European Communities, 15.11.2001, L 297/7.

${ }^{3}$ Videti: "Council Decision of 8 November 2007 establishing a Community Civil Protection Mechanism”, Official Journal of the European Union, L 314, Vol. 50, 1 December 2007.
} 
- "Council Decision of 5 March 2007 establishing a Civil Protection Financial Instrument", Official Journal of the European Union, L71, 10.03.2007.

- "Council Decision of 8 November 2007 establishing a Community Civil Protection Mechanism", Official Journal of the European Union, L 314, Vol. 50, 1 December 2007.

"Council decision of 23 October 2001 establishing a Community mechanism to facilitate reinforced cooperation in civil protection assistance intervention", Official Journal of the European Communities, L 297/7, 15.11.2001.

\section{3) SADRŽAJ}

Odluka br. 1313/2013/EU Evropskog parlamenta i Saveta od 17. decembra 2013. godine o Mehanizmu civilne zaštite Unije (dalje: Odluka) sastavljena je od 7 poglavlja, odnosno 38 članova.

U prvom poglavlju definisani su opšti i posebni ciljevi, najvažnija pitanja, kao i opseg primene Odluke. Takođe, u prvom poglavlju definisani su ključni termini od značaja, kao što su: katastrofa, odgovor, spremnost, prevencija, rano upozoravanje, procena rizika i slično. Važnost prvog poglavlja proizilazi iz detaljnog definisanja specifičnih ciljeva koji se Mehanizmom Unije žele postići, kao i iz utvrđivanja opsega njegove primene. U član 1 navodi se da je cilj Mehanizma Unije jačanje saradnje i bolja koordinacija između država članica u oblasti civilne zaštite. Rezultat jačanja međusobnih veza treba da bude efikasnija prevencija, priprema i odgovor na razne vrste katastrofa. Važno je pomenuti i stav 2 istog člana u kome se navodi da je zaštita stanovništva primarni cilj u slučaju vanrednih situacija i aktiviranja Mehanizma Unije. U članu 1 se takođe navodi da Mehanizam Unije treba da osnaži promociju solidarnosti između država članica kroz praktičnu saradnju i koordinaciju. U opseg delovanja Mehanizma Unije, koji je utvrđen članom 2 Odluke, spadaju aktivnosti prevencije i pripravnosti unutar Unije, ali i izvan nje. Takođe, u opseg delovanja spadaju i aktivnosti pružanja pomoći u reagovanju na neposredne štetne posledice katastrofe unutar ili izvan Unije. Aktivnosti van Unije mogu se realizovati tek nakon zahteva za pomoć putem Mehanizma Unije. U članu 3 definisani su specifični ciljevi Mehanizma Unije, a u njih spadaju: (1) postizanje visokog nivoa zaštite od katastrofa sprečavanjem ili smanjenjem njihovih potencijalnih efekata, negovanjem kulture prevencije i unapređenjem saradnje, (2) povećanje spremnosti, (3) olakšavanje brzog i efikasnog reagovanja, i (4) podizanje svesti javnosti i spremnosti za katastrofe.

Drugim poglavljem utvrđene su aktivnosti koje spadaju pod prevenciju. U navedene aktivnosti spada: (1) preduzimanje akcije za poboljšanje baze znanja o rizicima od katastrofa i olakšavanje razmene znanja, najboljih praksi i informacija, (2) podržavanje i promovisanje procene rizika država članica i njihovih aktivnosti u oblasti mapiranja, (3) uspostavljanje i redovno ažuriranje međusektorskog pregleda i mapiranja raznih katastrofa sa kojima se Unija može suočiti, (4) 
podsticanje razmene dobrih praksi u pripremi nacionalnih sistema civilne zaštite, (5) promovisanje, podržavanje razvoja i sprovođenje aktivnosti upravljanja rizicima država članica, (6) prikupljanje i širenje informacija koje su dostupne od strane država članica, uz organizovanje razmene iskustava u vezi sa sposobnošću upravljanja rizikom, (7) periodično izveštavanje u skladu sa utvrđenim rokovima, (8) promovisanje upotrebe različitih fondova Unije koji su namenjeni jačanju prevencije katastrofa, (9) isticanje značaja prevencije rizika i podržavanje država članica u podizanju svesti, javnom informisanju i obrazovanju, (10) promovisanje mera prevencije u državama članicama i trećim državama, i (11) preduzimanje dodatnih neophodnih pratećih preventivnih akcija, ali uz bliske konsultacije između država članica.

Treće poglavlje odnosi se na pripremljenost država članica, kao i nadležnih organa EU. Članom 7 osniva se Koordinacioni centar za odgovor na vanredne situacije (Emergency Response Coordination Centre - ERCC). Ovaj centar biće operativan 24 časa dnevno i biće na raspolaganju državama članicama i Evropskoj komisiji u skladu sa ciljevima Mehanizma Unije. Članom 8 definisane su nadležnosti Evropske komisije u oblasti preventivnih aktivnosti. U njih spadaju: (1) upravljanje ERCC-om, (2) upravljanje Zajedničkim sistemom komunikacije i informisanja u vanrednim situacijama, (3) doprinos razvoju i boljoj integraciji transnacionalnih sistema detekcije i ranog upozoravanja i uzbunjivanja, (4) uspostavljanje i upravljanje kapacitetima za mobilizaciju i slanje stručnih timova sa različitim zadacima, (5) uspostavljanje i održavanje pružanja logističke podrške tim stručnim timovima, (6) razvijanje i održavanje mreže obučenih stručnjaka iz država članica, (7) olakšavanje koordinacije u preliminarnom definisanju kapaciteta država članica za odgovor na katastrofe unutar Unije, (8) podržavanje napora za poboljšanje interoperabilnosti i drugih kapaciteta za reagovanje, (9) preduzimanje, u okviru svojih nadležnosti, neophodnih radnji radi olakšavanja podrške državi domaćinu, (10) podržavanje kreiranja programa dobrovoljne recenzije strategija država članica, i (11) u bliskoj konsultaciji sa državama članicama preduzimanje dodatnih aktivnosti pružanja podrške u cilju jačanja spremnosti za katastrofe. U članu 9 definisane su aktivnosti u oblasti spremnosti koje države članice treba da preduzmu. Države članice na dobrovoljnoj osnovi treba da rade na razvoju delova sistema koji su usmereni ka realizaciji prioritetnih intervencija ili potreba podrške u okviru Mehanizma Unije. U ostale zadatke država članica spada: (1) oblikovanje delova sistema unapred, (2) definisanje drugih kapaciteta za reagovanje i (3) određivanje stručnjaka u okviru svojih nadležnih službi, a posebno u okviru sopstvenih sistema civilne zaštite ili drugih službi za vanredne situacije. Te nadležne službe treba na zahtev, preko Mehanizma Unije, da budu dostupne za intervenciju. Države članice treba da uzmu u obzir da sastav delova sistema ili drugih kapaciteta za odgovor može da zavisi od vrste katastrofe i posebnih potreba povezanih sa katastrofom. Zajedničke aktivnosti Evropske komisije i država članica u oblasti spremnosti na katastrofe definisane su članom 10. Evropska komisija i države 
članice sarađivaće na poboljšanju planiranja operacija prilikom reagovanja na katastrofe u okviru Mehanizma Unije. To uključuje i kreiranje scenarija za reagovanje na katastrofe, mapiranje imovine i razvoj planova za raspoređivanje kapaciteta za reagovanje. Takođe, Evropska komisija i države članice zajednički identifikuju i promovišu objedinjavanje kapaciteta civilne zaštite i finansiranje humanitarne pomoći, a koje obezbeđuje EU i države članice tokom planiranja operacija reagovanja na humanitarne krize izvan Unije.

Četvrto poglavlje tiče se odgovora u slučaju katastrofa. U članu 14 utvrđen je prvi zadatak države članice u slučaju vanredne situacije. Država članica u kojoj je nastala vanredna situacija koja se može preneti na druge države članice dužna je, bez obzira da li se katastrofa dogodila ili postoji izvesnost da će se dogoditi, da bez odlaganja obavesti potencijalno pogođene države članice. Sa druge strane, Komisija je dužna da obavesti one države članice u kojima će efekti katastrofe biti značajni. U stavu 2 člana 14 navedeno je da u slučaju katastrofe unutar EU ili postojanja neposredne opasnosti od katastrofe, a koja će verovatno rezultirati pozivom za pomoć jedne ili više država članica, država članica u kojoj se katastrofa dogodila, ili je izvesno da će se dogoditi, mora odmah da obavesti Evropsku komisiju da postoji mogućnost za aktiviranjem ERCC-a. Time se Evropskoj komisiji omogućava da u skladu sa situacijom obavesti ostale države članice i aktivira svoje nadležne službe. U članu 15 navedeno je da je država članica koja je podnela zahtev za pomoć ERCC-a odgovorna za usmeravanje intervencija pomoći. Vlasti države članice treba da utvrde smernice i okvire zadataka koji su povereni interventnim timovima ili drugim subjektima. Detalji izvršenja tih zadataka prepuštaju se odgovornoj osobi koju je imenovala država članica koja pruža pomoć. Država članica koja je tražila pomoć može tražiti i raspoređivanje stručnog tima, čime bi se, između ostalog, olakšala koordinacija na terenu između timova država članica ili koji bi mogao da pruži tehničke savete. Nadležnosti Evropske komisije neće uticati na nadležnosti i odgovornost država članica za njihove timove, delove sistema i druge kapacitete podrške. Konkretnije, podrška Evropske komisije ne podrazumeva komandovanje i kontrolu nad timovima, delovima sistema i drugim kapacitetima država članica, koja će biti raspoređena na dobrovoljnoj osnovi u skladu sa koordinacijom na licu mesta i u formiranom štabu. Važno pitanje reguliše član 16, a tiče se pojave ili izvesnosti nastanka katastrofe u državama koje nisu članice EU. Kada se katastrofa dogodi izvan Unije, ili je izvesno da će se dogoditi, pogođena država može zatražiti pomoć putem ERCC-a. Takođe, pomoć se može zatražiti i kroz Ujedinjene nacije (UN), kao i kroz odgovarajuću međunarodnu organizaciju. Intervencije pomoći o kojima govori ovaj član mogu se sprovoditi u vidu pojedinačne nezavisne intervencije ili kao doprinos intervenciji koju vodi međunarodna organizacija. Koordinacija EU biće u potpunosti integrisana sa koordinacijom koju pruža Kancelarija Ujedinjenih nacija za koordinaciju humanitarnih poslova (United Nations Office for the Coordination of Humanitarian Affairs - OCHA) i poštovaće njenu vodeću ulogu. Član 16, stav 3 definiše aktivnosti 
kojima Evropska komisija treba da podrži konzistentnost u pružanju pomoći. Te aktivnosti su: (1) održavanje dijaloga sa kontaktnim tačkama država članica kako bi se osigurao efikasan i koherentan doprinos EU u odgovoru na katastrofe kroz mehanizam Unije, (2) što brže davanje preporuka u saradnji sa pogođenom državom na osnovu potreba na terenu, kao i na osnovu svih relevantnih i unapred razvijenih planova, (3) povezivanje sa pogođenom državom o tehničkim detaljima, (4) povezivanje ili podržavanje OCHA-e i saradnja sa drugim relevantnim akterima koji doprinose u pružanju pomoći, i (5) povezivanje sa svim relevantnim akterima, posebno u završnoj fazi intervencije.

U poglavlju pet utvrđene su finansijski kapaciteti za funkcionisanje Mehanizma Unije. Finansijska sredstva dodeljena za funkcionisanje Mehanizma Unije u periodu od 2014. do 2020. godine iznosiće oko 368,5 milona evra. Godišnja izdvajanja odobravaju Evropski parlament i Savet EU u okviru budžeta koji je definisan za period od nekoliko godina. Raspoređivanje finansijskih sredstava može se odnositi i na pokrivanje troškova za pripreme, nadgledanje, kontrolu, reviziju i evaluaciju, a koje su neophodne za upravljanje Mehanizmom Unije i postizanje njegovih ciljeva. Takođe, neki od izdataka koji mogu biti pokriveni ovim sredstvima odnose se na studije, sastanke eksperata, razvoj mreža internet-tehnologija, aktivnosti informisanja i komunikacije, što podrazumeva i korporativnu komunikaciju o političkim prioritetima Unije, ali samo ako su povezani sa opštim ciljevima Mehanizma Unije. Članovima 20, 21, 22 i 23 utvrđene su konkretne aktivnosti koje se mogu finansirati iz ovih finansijskih sredstava. Te aktivnosti su podeljene na oblasti prevencije i pripreme, odgovora na katastrofe, opreme i transporta, kao i na opštu oblast.

Poglavljem šest su utvrđene opšte odredbe. U članu 28 navedeno je da je Mehanizam Unije otvoren je za učešće: (1) država Evropske asocijacije za slobodnu trgovinu (European Free Trade Association - EFTA) koje su članice Evropskog ekonomskog prostora (European Economic Area - EEA), a u skladu sa uslovima utvrđenim u Sporazumu o EEA, kao i za druge evropske države kada to omogućavaju sporazumi i procedure, i (2) države koje pristupaju EU, države kandidati i potencijalne države kandidati, a u skladu sa utvrđenim opštim načelima i opštim uslovima za učešće tih država u programima EU. U stavu 3 člana 28 navodi se da međunarodne ili regionalne organizacije mogu sarađivati u aktivnostima $u$ okviru Mehanizma Unije, ukoliko to dopuštaju relevantni bilateralni ili multilateralni sporazumi između tih organizacija i EU.

U sedmom poglavlju su navedene finalne odredbe. U članu 35 navodi se da će se aktivnosti koje su pokrenute pre 1. januara 2014. godine na osnovu Odluke 2007/162/ EC, a koja se tiče Finansijskog instrumenta civilne zaštite, i dalje sprovoditi gde je to potrebno u skladu sa tom odlukom. Države članice se obavezuju da na nacionalnom nivou osiguraju nesmetan prelazak između aktivnosti 
sprovedenih u kontekstu Finansijskog instrumenta civilne zaštite i onih koje treba da se sprovedu u skladu sa odredbama ove Odluke. ${ }^{4}$

\section{4) DATUM STUPANJA NA SNAGU}

Usvajanje Odluke obavljeno je u Briselu 17. decembra 2013. godine. Odluka br. 1313/2013/EU Evropskog parlamenta i Saveta od 17. decembra 2013. godine o Mehanizmu civilne zaštite Unije stupila je na snagu jedan dan nakon objavljivanja u Službenom listu Evropske unije. Na snazi je od 1. januara 2014. godine. Odluka se odnosi na sve države članice EU, u skladu sa sporazumima EU.

\section{5) ZNAČAJ ZA REPUBLIKU SRBIJU}

Aktuelna politika Republike Srbije kreće se u pravcu pristupanja EU. To će zahtevati da Srbija uskladi svoje planove i strategije u oblasti civilne zaštite sa istim planovima i strategijama koje postoje u EU. Zato je važno da u ovom trenutku, dok Srbija pregovara sa EU o pristupanju, funkcionisanje sistema civilne zaštite u Srbiji bude što bliži standardima koji postoje u EU. Jedan od najvažnijih koraka u tom pravcu je usklađivanje domaćeg zakonodavstva sa zakonodavstvom EU u oblasti katastrofa i vanrednih situacija.

Osnovni cilj usklađivanja funcionisanja sistema civilne zaštite u Srbiji sa standardima EU je veća efikasnost ovog sistema u slučaju vanrednih situacija. Pravac standardizacije koji se realizuje u Srbiji usmeren je, pre svega, ka usaglašavanju sa normama i procedurama koje postoje u EU. Sektor za vanredne situacije formiran je sredinom 2009. godine i to predstavlja jedan od važnih rezultata u procesu reforme sistema civilne zaštite u Srbiji. Sektor za vanredne situacije spada u Ministarstvo unutrašnjih poslova Republike Srbije (MUP). Zato trenutno u Srbiji u oblasti civilne zaštite MUP ima najvažnije mesto. U skladu sa tim, MUP je najvažniji subjekt u procesu kreiranja i sprovođenja aktivnosti u oblasti civilne zaštite. ${ }^{5}$

Tokom septembra 2009. godine usvojen je "Akcioni plan za formiranje jedinstvene službe za vanredne situacije". Najvažniji cilj donošenja ovog dokumenta bilo je kreiranje jedinstvenog sistema upravljanja vanrednim situacijama. Time se omogućava angažovanje svih raspoloživih subjekata i kapaciteta u istom vremenskom periodu. Pretpostavka je da će se time povećati efikasnost u odgovoru na potencijalne rizike i moguće katastrofe, a istovremeno i u uklanjanju posledica

\footnotetext{
${ }^{4}$ Videti: "Decision No 1313/2013/EU of the European Parliament and of the Council of 17 December 2013 on a Union Civil Protection Mechanism", Official Journal of the European Union, L 347, 20 December 2013.

${ }^{5}$ Videti: „Zakon o vanrednim situacijama”, Službeni glasnik RS, br. 93/2012, čl. 11.
} 
nakon završetka vanredne situacije. To je predstavljalo još jedan važan korak u unapređenju sistema civilne zaštite u Srbiji. Usvajanje Akcionog plana imalo je kao primarni cilj usaglašavanje aktivnosti kojima se u slučaju vanredne situacije štite životi ljudi, imovina i životna sredina. Konkretnije, objedinjena služba za vanredne situacije treba da bude sposobna za brzo reagovanje, čime se povećava efikasnost aktivnosti ove službe u slučaju katastrofa. Može se reći da je usvajanje Akcionog plana predstavljalo dobru osnovu za poboljšanje programa obuke i bolje opremanje spasilačkih timova koji predstavljaju okosnicu za delovanje u vanrednim situacijama. Uspostavljanje jedinstvenog komandno-operativnog centra koji treba da koordinira aktivnosti nadležnih subjekata za delovanje u vanrednim situacijama takođe je planirano ovim Akcionim planom. ${ }^{6}$

Zakonodavni okvir u Republici Srbiji, koji se tiče prevencije u slučaju katastrofa, dodatno je ojačan „Zakonom o smanjenju rizika od katastrofa i upravljanju vanrednim situacijama", koji je usvojen 2018. godine. U njemu su definisane glavne aktivnosti kojima se smanjuje rizik od nastanka katastrofa, a u njih spada: (1) precizno identifikovanje, redovna procena i praćenje rizika od katastrofa radi njihove kontrole, (2) smanjenje dejstva faktora koji uzrokuju ili uvećavaju rizike od katastrofa, (3) ublažavanje štetnih posledica na osnovu što potpunijeg razumevanja rizika od njih, (4) obnovu nakon katastrofe u skladu sa načelom izgradnje boljeg sistema, (5) investiranje u prevenciju i smanjenje rizika od katastrofa kroz podsticanje javnog i privatnog ulaganja i preduzimanja strukturnih i nestrukturnih mera, (6) izgradnja kulture bezbednosti i otpornosti pojedinaca i zajednice na katastrofe, (7) intenzivna međusobna saradnja svih nadležnih institucija na svim nivoima vlasti, kao i partnerstvo sa privatnim i javnim preduzećima, drugim pravnim licima, preduzetnicima, organizacijama civilnog društva i svim zainteresovanim građanima, (8) uspostavljanje preciznih procedura za razmenu informacija i iskustava, i (9) praćenje klimatskih promena i prilagođavanje zajednice na očekivane posledice. Navedene aktivnosti treba da ojačaju otpornost i da bolje pripreme društvo za odgovor i ublažavanje posledica od nastalih katastrofa. ${ }^{7}$

Usvajanje „Nacionalne strategije zaštite i spasavanja u vanrednim situacijama” predstavljalo je novi korak u razvoju i osavremenjivanju sistema civilne zaštite u Srbiji. Jedan od osnova za izradu ove Strategije je „Nacionalni program za integraciju

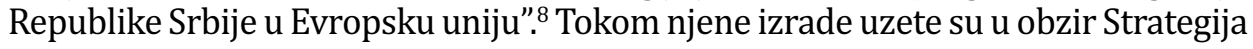
unutrašnje bezbednosti Evropske unije i Strategija Evropske unije za podršku

\footnotetext{
${ }^{6}$ Videti: „Akcioni plan za formiranje jedinstvene službe za vanredne situacije”, Službeni glasnik $R S$, br. 78/2009.

${ }^{7}$ Videti: „Zakon o smanjenju rizika od katastrofa i upravljanju vanrednim situacijama”, Službeni glasnik RS, br. 87/2018, čl. 11.

${ }^{8} 0$ tome videti detaljnije: „Izmenjeni i dopunjeni Nacionalni program za integraciju Republike Srbije u Evropsku uniju", Vlada Republike Srbije, Beograd, decembar 2009. godine.
} 
smanjenju rizika od katastrofa u zemljama u razvoju. Ovom Strategijom su utvrđeni nacionalni mehanizmi koordinacije, kao i pravci aktivnosti tokom odgovora na katastrofe i prilikom uklanjanja njihovih posledica. Primarni cilj koji se želeo ostvariti donošenjem ove Strategije je uspostavljanje integrisanog sistema zaštite i spasavanja na teritoriji Srbije. Od posebne važnosti je činjenica da ova Strategija osigurava ispunjenje preporuka Evropske unije za razvoj sistema nacionalne zaštite. U Strategiji je navedeno da je EU uspostavila Mehanizam civilne zaštite Zajednice (stari naziv), sa ciljem olakšavanja saradnje u intervencijama pomoći civilne zaštite u hitnim slučajevima, odnosno kada pogođena država nema dovoljan nivo pripremljenosti za katastrofu. S obzirom na to da je Srbija u procesu pristupanja EU i da Mehanizam Unije omogućava učešće država kandidata, jedan od ciljeva izrade ove Strategije je uključivanje Srbije u pomenuti Mehanizam. ${ }^{9}$

Razvoj sistema civilne zaštite u Srbiji u poslednje dve decenije odvija se u skladu sa evropskim standardima. Srbija je tokom vremena uspostavila jedinstven sistem civilne zaštite kako bi se povećala efikanost raspoloživih kapaciteta i aktivnosti tokom vanrednih situacija. Unapređenje reagovanja u vanrednim situacijama u Srbiji dosta se oslanja na jačanje svesti građana o ozbiljnosti posledica katastrofa i sličnih događaja. Zato se dosta pažnje posvećuje preventivnom delovanju nadležnih organa, službi, kao i samih građana. Još jedan aspekt unapređenja sistema civilne zaštite kome se dosta povetilo pažnje u prethodnim godinama je efikasnost u uklanjanju posledica nakon katastrofa. Zato je jedan od fokusa unapređenja sadašnjeg sistema civilne zaštite razvoj „kulture prevencije” među adekvatnim subjektima i građanima. Takođe, treba naglasiti da je Srbija u prethodnom periodu dosta energije uložila u unapređenje vatrogasno-spasilačkih jedinica u skladu sa standardima EU. Time se dosta učinilo i na unapređenju civilne zaštite, jer su ove jedinice okosnica sistema civilne zaštite u državama EU. Ukratko, efikasnije vatrogasno-spasilačke jedinice znače ujedno i efikasniju civilnu zaštitu. Da bi Srbija dodatno unapredila svoj sistem civilne zaštite neophodno je formiranje objedinjenog sistema obaveštavanja u slučaju katastrofa. Radi se, recimo, o broju 112 koji bi služio u tu svrhu. Do sada su u Srbiji postojali planovi za uvođenje ovog broja, ali nijedan nije zaživeo. To bi bio dobar početak, a zatim bi trebalo objediniti planove zaštite u slučaju katastrofa na lokalnom, pokrajinskom i republičkom nivou. Zakonski okvir u Srbiji je dobro uređen, ali je potrebno više učiniti u praksi, a posebno kada se govori o ulaganju finansijskih sredstava. Organizacija civilne zaštite u Srbiji je solidno uređena, ali ako naša zemlja želi da bude pouzdan partner u okviru Mehanizma Unije mora još da učini na unapređenju svog sistema. Jedan od načina za rešavanje postojećih problem, pored dodatnih finansijskih ulaganja, je još detaljnije usklađivanje sa standardima EU u navedenoj oblasti. Tokom tog

\footnotetext{
${ }^{9}$ Videti: „Nacionalna strategija zaštite i spasavanja u vanrednim situacijama”, Službeni glasnik $R S, 86 / 2011$ od 18.11.2011. godine.
} 
usklađivanja Srbija bi mogla da stekne nova iskustva i lakše savlada predstojeće izazove u unapređenju domaćeg sistema civilne zaštite. Time bi se uklonili nedostaci u postojećem sistemu i bilo bi lakše formirati kompaktan sistem koji je u svakom trenutku spreman da pruži efikasan odgovor na potencijalne katastrofe, kao i na one koje su u toku.

\section{DECISION no. 1313/2013/EU OF THE EUROPEAN PARLIAMENT AND OF THE COUNCIL OF 17 DECEMBER 2013 ON A UNION CIVIL PROTECTION MECHANISM}

Summary: Prevention of different disasters is one of the key aspects of the European Union's stronger activities in the area of civil protection. The goal was to create more efficient civil protection in accordance with modern threats brought by disasters. For this reason, the European Union created the Union Civil Protection Mechanism. The purpose of this Mechanism is to make the activities of the European Union in the field of prevention and disaster consequences elimination more efficient. Maybe the most important reason is many times seen phenomenon that a disaster in one state causes consequences in another. Sometimes a disaster appears in several neighboring countries at the same time. In the case of the European Union that also means that the disaster in a state which is not a member can also hit some of the member states. Because of the consequences, every disaster is provoking redirection of financial and economic resources. It always strongly affects the normal functioning of every member state and also the European Union as a whole. These facts caused the creation of the Union Civil Protection Mechanism with the primary goal to prevent possible disasters. On the other hand, the purpose of this Mechanism is to enable the fast stabilization of the economic and political systems of the member states after a disaster.

Keywords: Prevention, disasters, emergency situations, civil protection, Union Civil Protection Mechanism, European Union, Serbia. 